\title{
Review of research on haploid production in cucumber and other cucurbits
}

\author{
Joanna Gatazka*, Katarzyna Niemirowicz-Szczytt \\ Department of Plant Genetics, Breeding and Biotechnology \\ Warsaw University of Life Sciences \\ 156 Nowoursynowska St, 02-776 Warsaw, Poland
}

\begin{abstract}
This review provides a summary of haploid induction methods and factors affecting the efficacy of specific methodologies as applied to cucumber (Cucumis sativus L.), melon (Cucumis melo L.), watermelon (Citrullus lanatus (Thunb.) Matsum. \& Nakai), winter squash (Cucurbita maxima Duch. ex Lam.), summer squash (Cucurbita реро L.) and other cucurbits. This report is focused on studies that were carried out during the last 20 years.

The main objective of the research on the production of haploid cucurbit plants is to accelerate breeding programs through the use of homozygous double haploid lines (DHL) and to facilitate the selection of desired (e.g. disease-resistant) genotypes for breeding. Unfortunately, currently used protocols result in a low number of double haploids (DH). The most common and best-known method of obtaining haploid cucurbit plants is via pollination with irradiated pollen, which induces parthenogenetic development of haploid embryos in planta. The embryos are extracted from immature seeds and cultured in vitro to facilitate the maturation and development of plants. The studies described below were primarily aimed at the determination of an appropriate dose of radiation and the evaluation of the impact of the genotype and the time of year on the number of haploid embryos and plants obtained.

A less popular method of haploid production - ovule and ovary culture - is based on in vitro gynogenesis. The studies related to this method concentrated on optimising the composition of the medium and pre-treatment conditions (primarily temperature) to which the flower buds were subjected.

Recently, increasing attention has been paid to anther and microspore culture. As in the case of in vitro ovule and ovary culture, the medium composition and flower bud pre-treatment conditions were optimised. The most recent studies suggest that anther culture is comparable in effectiveness to the irradiated pollen technique.
\end{abstract}

Key words: androgenesis, Cucurbitaceae, double haploid, gynogenesis, microspore culture, in vitro, irradiated pollen

\section{INTRODUCTION}

Haploid plants predominantly originate from meiotically reduced tissue that undergoes embryogenesis without fertilisation. Therefore, one can define haploids as plants containing a gametic number of chromosomes in a sporophyte. Interest in haploids began with observations by Dorothy Bergner in 1921 of Datura stamonium L. haploid plants, described by Blakeslee et al. (1922).

The most important achievements and milestones, such as the development of protocols to

\footnotetext{
*Corresponding author.

Tel.: +48 2259321 29; fax: +48 225932152 ;

e-mail: joanna_galazka@sggw.pl (J. Gałązka).
} 
produce haploid plants in the laboratory, the release of the first DH crop plant and the use of DHs in genetic analysis (e.g. establishing chromosomes maps), in haploid research and history were described by Forster et al. (2007). More recently Dunwell (2010) described in his comprehensive review a range of techniques that are available for the isolation or induction of haploids. Although several general reviews on haploid production have been published to date, only a few publications summarise the research in the field of cucurbit haploids. A short review by Przyborowski (1996) on haploids in cucumber (Cucumis sativus L.) was published in a series entitled In Vitro Haploid Production in Higher Plants. More recently, a brief report on haploid induction in Cucurbitaceae species was released by Gémes Juhász and Jakše (2005) in the Biotechnology in Agriculture and Forestry series. Still, no comprehensive review in this area has been published so far. The review presented here describes the most popular methods of obtaining haploid cucurbits, i.e. pollination with irradiated pollen, ovule/ovary culture and anther/ microspore culture. It also analyses the factors that influence the success rate of each method. The most important results are summarized in Table 1. The listed publications do not refer to chromosome doubling of haploids.

\section{The importance of double haploid lines in breeding}

The main objective of the haploid research is to obtain homozygous double haploid lines (DHLs) suitable for breeding programmes. The list of cultivars obtained through the application of DHLs (representing various genera and species) comprises nearly three hundred citations (http:// www.scri.ac.uk/assoc/COST851/DHTable2005. xls). Half of the list (148 entries) is comprised of barley cultivars. In addition, the list includes rape (52), wheat (36), rice (11), melon (9), pepper (8), asparagus (7), tobacco (6), eggplant (5), triticale (3), Indian mustard (2) and turnip (1) cultivars.

The main emphasis in the literature describing cucumber haploids and double haploids (DHs) is on the efficiency of the methodology, i.e. the number of obtained haploids and DHs. Information about the number of DHs that were further advanced and used in the production of homozygous lines, which would be useful in breeding, is frequently missing.

In the case of cucumber, the development of homozygous parental lines using the traditional self-pollination method takes from six to eight years
(Gémes Juhász et al. 2002). According to Claveria et al. (2005), Dolcet-Sanjuan et al. (2006) and our experience with the Polish cucumber cultivars, the irradiated pollen method can be routinely applied to accelerate breeding programs and to achieve complete homozygosity in one generation, although the number of DHLs obtained is usually low.

DHs can facilitate the selection of desirable genotypes for further breeding. Lofti et al. (2003) used hybrids resulting from crosses between lines with various disease resistance characteristics as donor plants for haploid and $\mathrm{DH}$ production to facilitate the recovery of melon (Cucumis melo L.) cultivars resistant to several viruses. Research on melon carried out by Kuzuya et al. (2003) indicated that the selection for resistance to powdery mildew caused by Sphaerotheca fuliginea could be applied to the haploid plants. More than half of the haploid plants displayed the same level of resistance as the donor plants. In addition, haploid and double haploid plants are also used in basic research. For example, Gonzalo et al. (2005) used DHL populations to construct a genetic map of melon.

\section{The beginnings of haploid induction in the Cucurbitaceae family}

The first haploid plants in the Cucurbitaceae family were obtained in the 1950s. In 1958 Aalders isolated haploid embryos from normal seeds of cucumber, while Swaminathan and Singh (1958) observed a haploid shoot of watermelon (Citrullus lanatus (Thunb.) Matsum. \& Nakai) on a diploid plant grown from an X-ray treated seed. Hayase (1954) obtained a haploid plant of winter squash (Cucurbita maxima Duch. ex Lam.) by pollination with Cucurbita moschata Duch. ex Poir. A similar method (pollination with Cucumis ficifolius A. Rich.) was used by Dumas de Vaulx (1979), who obtained the first haploids of C. melo.

The first haploid plants of Cucurbita pepo L. (summer squash) were obtained by Dumas de Valux and Chambonnet in 1986 using a non-fertilised ovule culture. Furthermore, Zagorcheva et al. (1987) found an apomictic haploid plant among the progeny of $C$. ficifolius obtained after isolation of a non-fertilised female flower. In the $1980 \mathrm{~s}$, attempts were made to obtain haploid plants from anthers of C. maxima, C. moschata, C. pepo, Luffa cylindrica Mill. (smooth loofah) and Trichosanthes dioica Roxb. (pointed gourd) (Kumar 1984, Shail and Robinson 1987). However, the data on the results is limited. 
Table 1. Methods and results of selected protocols for haploid induction in cucurbits

\begin{tabular}{|c|c|c|c|}
\hline Species & Method & Result & References \\
\hline \multirow{3}{*}{$\begin{array}{l}\text { C. lanatus } \\
\text { watermelon }\end{array}$} & \multirow{2}{*}{ A } & $\mathrm{p}$ & Li et al. 2008 \\
\hline & & $\mathrm{pH}$ & Xue et al. 1983 \\
\hline & Pirr & $\mathrm{pH}$ & Gürsöz et al. 1991; Sari et al. 1994 \\
\hline $\begin{array}{l}\text { C. ficifolius } \\
\text { cucumis }\end{array}$ & ap & $\mathrm{pH}$ & Zagorcheva et al. 1987 (apomixis in isolated flower) \\
\hline \multirow{5}{*}{$\begin{array}{l}\text { C. melo } \\
\text { melon }\end{array}$} & \multirow{2}{*}{ G } & $\mathrm{p}$ & Lofti et al. 2003 \\
\hline & & $\mathrm{pD}, \mathrm{pH}, \mathrm{pM}$ & Ficcadenti et al. 1999 \\
\hline & \multirow[t]{2}{*}{ Pirr } & $\mathrm{pH}$ & $\begin{array}{l}\text { Sauton and Dumas de Vaulx 1987, 1988; Sauton 1988; Cuny et al. 1993; } \\
\text { Ficcadenti et al. 1995; Yanmaz et al. 1999; Lim and Earle 2008; Godbole and } \\
\text { Murthy 2012; Sari et al. } 2010\end{array}$ \\
\hline & & $\mathrm{pD}, \mathrm{pH}, \mathrm{pM}$ & Lofti et al. 2003; Ari et al. 2010 \\
\hline & px & $\mathrm{pH}$ & Dumas de Vaulx 1979 (pollination with C. ficifolius) \\
\hline \multirow{17}{*}{$\begin{array}{l}\text { C. sativus } \\
\text { cucumber }\end{array}$} & \multirow{4}{*}{ A } & co & Xie et al. 2005; Suprunova and Shmykova 2008; Abd El-Maksoud et al. 2009 \\
\hline & & $\mathrm{p}$ & Lazarte and Sasser 1982, \\
\hline & & $\mathrm{pD}, \mathrm{pH}$, & Ashok Kumar et al. 2003, 2004; Ashok Kumar and Murthy 2004 \\
\hline & & $\begin{array}{l}\mathrm{pD}, \mathrm{pDH}, \mathrm{pH} \\
\mathrm{pM}, \mathrm{pT}\end{array}$ & Song et al. 2007 \\
\hline & \multirow{5}{*}{ G } & e & Gémes Juhász et al. 1997 \\
\hline & & $\mathrm{p}$ & Suprunova and Shmykova 2008 \\
\hline & & $\mathrm{pDH}, \mathrm{pH}$ & Dirks 1996 (patent) \\
\hline & & $\mathrm{pDH}, \mathrm{pH}, \mathrm{pM}$ & Gémes Juhász et al. 2002 \\
\hline & & $\begin{array}{l}\text { pD, pDH, pH, } \\
\text { pT }\end{array}$ & Diao et al. 2009 \\
\hline & \multirow{3}{*}{ M } & co & Suprunova and Shmykova 2008 \\
\hline & & $\mathrm{p}$ & Zhan et al. 2009 \\
\hline & & $\mathrm{pDH}, \mathrm{pH}$ & Chen et al. 2008 (patent) \\
\hline & \multirow[t]{4}{*}{ Pirr } & $\mathrm{pH}$ & $\begin{array}{l}\text { Troung-Andre 1988; Sauton 1989; Przyborowski and Niemirowicz-Szczytt } \\
\text { 1992; Niemirowicz-Szczytt et al. 1995; Çağlar and Abak 1996a,b, 1999a,b; } \\
\text { Faris et al. 1999; Lofti et al. 1999; Niemirowicz-Szczytt et al. 2001; Claveria et } \\
\text { al. 2005; Dolcet-Sanjuan et al. 2006; Sztangret-Wiśniewska et al. 2006; Lofti } \\
\text { and Salehi } 2008\end{array}$ \\
\hline & & $\mathrm{pA}, \mathrm{pH}$ & Przyborowski and Niemirowicz-Szczytt 1994 \\
\hline & & $\mathrm{pA}, \mathrm{pD}, \mathrm{pH}$ & Niemirowicz-Szczytt and Dumas de Vaulx 1989 \\
\hline & & $\mathrm{pD}, \mathrm{pH}$ & Le Deunff and Sauton 1994 \\
\hline & $\mathrm{sp}$ & $\mathrm{pH}$ & Aalders 1958 \\
\hline \multirow{3}{*}{$\begin{array}{l}\text { C. maxima } \\
\text { winter squash }\end{array}$} & A & co & Shail and Robinson 1987 \\
\hline & Pirr & $\mathrm{pH}$ & Kurtar and Balkaya 2010 \\
\hline & $\mathrm{px}$ & $\mathrm{pH}$ & Hayase 1954 (pollination with C. moschata) \\
\hline \multirow{3}{*}{$\begin{array}{l}\text { C. moschata } \\
\text { squash }\end{array}$} & A & co & Shail and Robinson 1987 \\
\hline & G & $\mathrm{e}$ & Kwack and Fujieda 1988 \\
\hline & Pirr & $\mathrm{pH}$ & Kurtar et al. 2009 \\
\hline \multirow{9}{*}{$\begin{array}{l}\text { C. pepo } \\
\text { summer squash }\end{array}$} & \multirow{3}{*}{ A } & $\mathrm{p}$ & Shail and Robinson 1987 \\
\hline & & $\mathrm{pA}, \mathrm{pD}, \mathrm{pH}$ & Mohamed and Refaei 2004 \\
\hline & & $\mathrm{pD}, \mathrm{pH}$ & Metwally et al. $1998 \mathrm{~b}$ \\
\hline & \multirow{5}{*}{ G } & co & Shail and Robinson 1987 \\
\hline & & $\mathrm{p}$ & Xie et al. 2006 \\
\hline & & $\mathrm{pH}$ & Dumas de Vaulx and Chambonnet 1986; Gémes Juhász et al. 1997; \\
\hline & & $\mathrm{pD}, \mathrm{pH}$ & Metwally et al. 1998a; Shalaby 2007 \\
\hline & & $\begin{array}{l}\mathrm{pA}, \mathrm{pD}, \mathrm{pM}, \\
\mathrm{pP}\end{array}$ & Chambonnet and Dumas de Vaulx 1985 \\
\hline & Pirr & $\mathrm{pH}$ & Kurtar et al. 2002 \\
\hline
\end{tabular}


Table 1. (continued)

\begin{tabular}{|c|c|c|c|}
\hline Species & Method & Result & References \\
\hline $\begin{array}{l}\text { L. cylindrica } \\
\text { smooth loofah }\end{array}$ & A & $\mathrm{eD}, \mathrm{eH}$ & Kumar 1984 \\
\hline $\begin{array}{l}\text { M. charantia } \\
\text { bitter melon }\end{array}$ & A & co & Tang et al. 2012 \\
\hline $\begin{array}{l}\text { T. dioica } \\
\text { pointed gourd }\end{array}$ & $\mathrm{A}$ & $\mathrm{eD}$ & Kumar 1984 \\
\hline \multicolumn{4}{|c|}{$\begin{array}{l}\text { Methods: } \mathrm{A} \text { - anther culture, ap - apomixis, } \mathrm{G} \text { - ovule and/or ovary culture, } \mathrm{M} \text { - microspore culture, Pirr - pollination with } \\
\text { irradiated pollen, } \mathrm{sp} \text { - spontaneous parthenogenesis, } \mathrm{px} \text { - interspecific pollination induced parthenogenesis; } \\
\text { Results: } \mathrm{e} \text { - embryos only (no plants), co - callus only, } \mathrm{p} \text { - plants, } \mathrm{A} \text { - aneuploid, } \mathrm{D} \text { - diploid, } \mathrm{DH} \text { - double haploid, } \mathrm{H} \text { - } \\
\text { haploid, } \mathrm{M} \text { - mixoploid, } \mathrm{P} \text { - other polyploids, } \mathrm{T} \text { - tetraploid. }\end{array}$} \\
\hline
\end{tabular}

\section{METHODS OF CUCURBIT HAPLOID INDUCTION}

There are several processes leading to obtaining haploid and DH cucurbits. These are primarily haploid parthenogenesis (induced primarily by pollination with irradiated pollen), in vitro gynogenesis (during in vitro culture of ovules and ovaries) and in vitro androgenesis (during in vitro culture of microspores and anthers).

\section{Pollination with irradiated pollen}

The induction of parthenogenetic development of the egg cell by pollination with irradiated pollen followed by haploid embryo rescue was first successfully used to obtain haploid embryos of melon and cucumber over 20 years ago (Sauton and Dumas de Vaulx 1987, 1988, Truong-Andre 1988, Niemirowicz-Szczytt and Dumas de Vaulx 1989). During the subsequent years, research was focused on the effect of the genotype, time of the year and radiation dose on the number of obtained haploids (Cuny et al. 1993, Przyborowski and NiemirowiczSzczytt 1994, Çağlar and Abak 1996a, 1999a, b, Faris et al. 1999, Lofti et al. 1999). Haploid plants of watermelon and summer squash were also obtained using irradiated pollen (Gürsöz et al. 1991, Sari et al. 1994, Kurtar et al. 2002).

Experiments on cucumber haploid induction with irradiated pollen have been conducted for about 20 years at the Department of Plant Genetics, Breeding and Biotechnology of the Warsaw University of Life Sciences in Poland. Pollination is routinely carried out on 40 plants per cultivar twice a year - in the spring and in late summer. The pollen is irradiated with a dose of 300 Gy (SztangretWiśniewska et al. 2006).

Recently, the application of this method resulted in haploid induction in C. maxima and C. moschata (Kurtar et al. 2009, Kurtar and Balkaya 2010). Further attempts have also been made to optimise the method for cucumber and melon (Lofti et al. 2003, Claveria et al. 2005, Lofti and Salehi 2008, Ari et al. 2010, Sari et al. 2010, Godbole and Murthy 2012). So far pollination with irradiated pollen has been the leading method of haploid induction in these two species.

\section{Efficiency of haploid recovery}

In cucumber, Sauton (1989) obtained an average of 0.9 haploid embryos per fruit (e/f). Przyborowski and Niemirowicz-Szczytt (1994) were able to obtain 4 e/f, while Çağlar and Abak (1996b) were able to achieve 16 e/f. In summer squash, Kurtar et al. (2002) obtained 7.5 e/f, while Sari et al. (2010) had 0.7 embryos per one melon fruit. Recently, an average efficiency of 13.7 embryos per fruit was obtained in winter squash (Kurtar and Balkaya 2010). The efficacy of embryo induction in cucumber and melon is determined by several factors, such as radiation dose, the genotype of the mother plants and the time of the year during which the pollination took place (Sauton 1988, 1989).

\section{Irradiation and pollination}

A low dose of gamma radiation, typically about $300 \mathrm{~Gy}$, was shown to be effective in experiments carried out on melon (Sauton 1988), and was also optimal in cucumber haploid production (Niemirowicz-Szczytt et al. 1995, Çağlar and Abak 1996a, 1999a). Faris et al. (1999) examined in detail the effect of the radiation dose on haploid embryo development using five lines and three hybrids of cucumber. The authors applied doses ranging from 50 to $300 \mathrm{~Gy}$ and found that $100 \mathrm{~Gy}$ was the optimal dose to induce haploid embryo development. Claveria et al. (2005) obtained higher induction levels with a higher dose of 500 Gy. Cuny et al. (1993) used doses of gamma radiation ranging from 150 to 2,500 $\mathrm{Gy}$, and did not observe a significant effect of the dose on the induction of melon haploids. These results suggest 
that the preferred radiation dose is specific to each particular experiment.

Cobalt $\left({ }^{60} \mathrm{Co}\right)$ is most commonly used as the source of $\gamma$-rays. Gamma radiation is easy to apply and, at the same time, it has good tissue penetration, induces a high mutation rate, and has low lethality (Kurtar and Balkaya 2010). However, other sources of radiation can be used as well, for example Antos et al. (2001) obtained cucumber haploids using pollen irradiated at 300 Gy using X-rays.

Usually, radiation is applied to flowers (frequently after the removal of sepals and petals) or to isolated anthers. For instance, Kurtar et al. (2009) used anthers of C. moschata, while Sari et al. (1994) used flower buds with partly removed sepals and petals in watermelon. Information about the pollination method is limited. It is known, however, that a large amount of irradiated pollen applied to stigmas can stimulate a parthenogenetic response by increasing the number of pollen tubes reaching the egg cell. This phenomenon was observed in melon (Sauton and Dumas de Vaulx 1987, Cuny et al. 1993).

\section{Donor plant genotype and vigour}

A significant effect of the genotype of the donor plants on haploid production was observed in cucumber, melon and summer squash (Sauton 1988, 1989, Cuny et al. 1993, Przyborowski and Niemirowicz-Szczytt 1994, Niemirowicz-Szczytt et al. 1995, Kurtar et al. 2002). Furthermore, vigour and physiological state of parental plants was important for the formation of melon haploids (Sauton 1988, Cuny et al. 1993).

Niemirowicz-Szczytt et al. (1995) used cucumber inbred lines and their hybrids as mother plants. The total number of haploid embryos obtained was higher when using hybrids as compared with inbred lines. Sestili and Ficcadenti (1996) observed significant differences among hybrids generated through diallel crosses of various lines as shown by the numbers of melon haploids obtained via pollination with irradiated pollen. Therefore, plant vigour seems to play an important role in the induction of haploid embryos.

\section{Time of the year}

The time of the year and the month during which pollination with irradiated pollen takes place also affects the outcome. Sauton (1988) reported the highest yield of melon haploids between June and September. In the case of cucumber, the number of embryos developing into haploid plants was higher in the summer than in the spring (Przyborowski and Niemirowicz-Szczytt 1994, Sztangret-Wiśniewska et al. 2006). Similarly, the highest number of haploid cucumber plants was obtained by Çağlar and Abak (1999a, b) in June and July. In the case of C. pepo, after pollination carried out from May to September, the largest number of embryos per fruit was obtained in September and June (Kurtar et al. 2002). In C. lanatus, C. moschata and C. maxima, a positive influence of the spring season on the yield of haploid embryos was observed (Gürsöz et al. 1991, Kurtar et al. 2009, Kurtar and Balkaya 2010).

\section{Embryo detection, excision and culture}

In addition to the factors mentioned above, the method of embryo detection and isolation as well as the manner of handling the seeds can affect the number of recovered haploids. The endosperm does not develop after pollination with irradiated pollen (Sauton and Dumas de Vaulx 1987, Sauton 1989, Faris and Niemirowicz-Szczytt 1999). The embryo grows initially even without the presence of endosperm, however its development is arrested at an early stage which necessitates embryo rescue and in vitro culture. Otherwise the embryo dies. The medium most commonly used for the rescue is the E20A medium, which was developed by Sauton and Dumas de Vaulx (1987) for melon haploid production.

One of the most common methods used for the detection and isolation of embryos consists of the physical opening of all seeds (Faris et al. 1999, Kurtar et al. 2002, Sari et al. 2010, Godbole and Murthy 2012). At the Department of Plant Genetics, Breeding and Biotechnology cucumber seeds are inspected over a light source and the transparent (empty) seeds are discarded. Another efficient method of embryo detection is the application of X-ray radiography of seeds (Savin et al. 1988, Le Deunff and Sauton 1994, Claveria et al. 2005, Dolcet-Sanjuan et al. 2006), which also enables the detection of seeds containing developing embryos.

Lofti et al. (2003) and Lofti and Salehi (2008) show that about 10 days of culture of seeds in liquid E20A medium, prior to embryo isolation, increases the number of haploid plants, likely due to the increased visibility of the embryos. However, Ari et al. (2010) pointed out the higher labour costs of the seed culture technique as compared to the inspection of seeds placed over a light source immediately after harvesting. Moreover, 
a liquid medium culture increases the risk of plant material losses due to microbial infection (Lofti et al. 2003).

\section{Ovule and ovary culture}

As compared to parthenogenesis induced by pollination with irradiated pollen, the information on successful ovule and/or ovary culture (in vitro gynogenesis induction) is rather sparse. This technique was used successfully to obtain haploids of summer squash, cucumber and melon (Dumas de Vaulx and Chambonnet 1986, Gémes Juhász et al. 1997, Metwally et al. 1998a, Ficcadenti et al. 1999, Gémes Juhász et al. 2002, Shalaby 2007, Suprunova and Shmykova 2008, Diao et al. 2009). Dirks (1996), Metwally et al. (1998a), Shalaby (2007) and Diao (2009) also obtained DHs in cucumber and summer squash by inducing in vitro gynogenesis.

Nunhems Zaden BV, a Dutch seed company, patented the method of obtaining haploids and DHs of cucumber with ovary culture (Dirks 1996); however, no data on the efficacy of this method and its subsequent application was released. The highest reported efficiency of regeneration was 7.1 and 9 regenerated plants per 100 cucumber ovaries cultured (Gémes Juhász et al. 2002 and Diao et al. 2009, respectively), and 11 regenerated plants per 100 C. pepo ovaries (Metwally et al. 1998a). Thus, as compared to pollination with irradiated pollen, ovary culture is a low efficiency method.

Optimisation experiments involved evaluations of the developmental stage of the embryo sac, medium composition and temperature pre-treatment (Chambonnet and Dumas de Vaulx 1985, Metwally et al. 1998a, Gémes Juhász et al. 2002). Histological studies of cucumber female gametophyte showed that a late stage of development (characterised by the presence of cells similar in shape and structure) was the most suitable for embryo induction. It was also possible to obtain haploid embryos from a mature embryo sac; however, it was impossible to obtain them from megaspores and during early stages of embryo sac development (Gémes Juhász et al. 2002). In cucumber, most embryos were obtained after harvesting ovaries six days before flowering (Gémes Juhász et al. 2002). C. pepo ovaries harvested one day before flowering yielded the highest number of embryos in the experiments of Chambonnet and Dumas de Vaulx (1985) and Metwally et al. (1998a). Various types of media have been used for in vitro gynogenesis induction. Metwally et al. (1998a) applied Murashige and Skoog (MS) medium with an addition of $1-5 \mathrm{mg} \mathrm{dm}^{-3}$ 2,4-D and $30 \mathrm{~g} \mathrm{dm}^{-3}$ of sucrose. Xie et al. (2006) used N6 medium with the addition of 2,4-dichlorophenoxyacetic acid (2,4-D), naphthalene-1-acetic acid and benzyladenine (BA). Gémes Juhász et al. (2002) carried out induction on their own CBM medium, enriched with $0.02 \mathrm{mg} \mathrm{dm}^{-3}$ of thidiazuron and $40 \mathrm{~g} \mathrm{dm}^{-3}$ of sucrose.

The impact of temperature pre-treatment (low or high temperature) on in vitro gynogenesis was also tested. Metwally et al. (1998a) found that haploid induction in summer squash was more efficient without a low temperature stress pretreatment. However, a high temperature pretreatment of ovaries $\left(28^{\circ} \mathrm{C}\right.$ or $\left.35^{\circ} \mathrm{C}\right)$ in the presence of thidiazuron increased the number of embryos and plants obtained in cucumber (Gémes Juhász et al. 2002). The optimisation of the methodology was continued by Shalaby (2007), Suprunova and Shmykova (2008) as well as Diao et al. (2009), who also studied the role of the genotype, flower position on shoots, temperature pre-treatment and medium composition on cucumber haploid production. The results of the presented studies indicate that in vitro ovule and ovary culture is a low efficiency method of cucurbit haploid induction, requiring further optimisation.

\section{Anther and microspore culture}

The results of the first studies on the induction of in vitro androgenesis in the Cucurbitaceae family, carried out on a limited scale on cucumber, watermelon, melon and summer squash, were limited to the production of mostly callus and only a small number of haploid plants (Lazarte and Sasser 1982, Dryanovska and Ilieva 1983, Xue et al. 1983, Shail and Robinson 1987). In vitro culture was also applied to the anthers of smooth loofah and pointed gourd by Kumar (1984), who obtained haploid and diploid embryos. In anther culture of balsam pear (Momordica charantia L.). Tang et al. (2012) observed only callus formation. In 1998 Metwally et al. (1998b) exposed C. pepo male flower buds to cold pre-treatment for four days at $4^{\circ} \mathrm{C}$. This treatment was applied to male flower buds with microspores at the mid or late uninucleate stage. When the anthers were placed on MS medium with $5 \mathrm{mg} \mathrm{dm}^{-3} 2,4-\mathrm{D}$ and $150 \mathrm{~g} \mathrm{dm}^{-3}$ of sucrose, the regeneration level reached 1.9 plants per anther (p/a). Similar experiments carried out by Mohamed and Refaei (2004) gave slightly better results $(2.6 \mathrm{p} / \mathrm{a})$. 
The in vitro culture of cucumber anthers resulted in callus development, followed by embryo development and organogenesis. However, haploid plants were not recovered and it was not reported from which tissues callus was formed (Lazarte and Sasser 1982).

Additional reports of cucumber anther culture have been published in the last 10 years. The anthers used contained microspores at the mid to late uninucleate stage. Ashok Kumar et al. (2003) examined in detail the effect of medium composition and flower bud cold pre-treatment on the regeneration of haploid and diploid plants. The highest rate of anthers producing embryogenic callus (54.4\%) was observed with a two-day cold pre-treatment. Similar results were obtained by Xie et al. (2005). Ashok Kumar et al. (2004) and Ashok Kumar and Murthy (2004) improved the method by enriching the induction medium with various kinds of sugars (sucrose, maltose, glucose and fructose), amino acids (glutamine, glycine, arginine, asparagine and cysteine) and polyamines (putrescine and spermidine). Their last experiments produced 1.6 embryos and 1.35 plantlets per anther placed on Gamborg B5 medium supplemented with $0.44 \mathrm{mg} \mathrm{dm}^{-3} 2,4-\mathrm{D}, 0.22 \mathrm{mg} \mathrm{dm}^{-3} \mathrm{BA}, 85 \mathrm{~g}$ $\mathrm{dm}^{-3}$ sucrose and $29 \mathrm{mg} \mathrm{dm}^{-3}$ spermidine (Ashok Kumar et al. 2004). In 2007 Song et al. released the data of six experiments aimed at a comprehensive analysis of the impact of such factors as cold pretreatment, physical conditions during in vitro culture, composition of induction medium and genotype on regeneration. As a result, the authors developed a protocol for anther culture that gave the highest efficiency (three embryos per anther and $0.9 \mathrm{DH}$ plants per anther). The best medium for embryonic callus induction was MS medium supplemented with $1 \mathrm{~g} \mathrm{dm}^{-3} \mathrm{BA}, 0.5 \mathrm{~g} \mathrm{dm}^{-3}$ 2,4-D, $1 \mathrm{~g} \mathrm{dm}^{-3}$ kinetin and $30 \mathrm{~g} \mathrm{dm}^{-3}$ sucrose while suitable temperature stress depended on the place of origin of each cultivar. The application of their protocol resulted in the production of double haploids, haploids, diploids and plants of other ploidy.

The formation of haploids and DHs from microspores as well as the formation of diploid plants from somatic tissue was observed in anther culture of cucumber (Ashok Kumar et al. 2003, Ashok Kumar and Murthy 2004, Song et al. 2007). Song et al. (2007) noted embryo regeneration only from callus (indirect embryogenesis), while Ashok Kumar and Murthy (2004) reported both direct and indirect embryogenesis. In the case of regenerated diploid plants one needs to determine their origin, whether it is gametophytic or sporophytic, e.g. with the use of molecular markers. This additional analysis could be avoided with the application of microspore culture instead of anther culture.

Only a few researchers attempted to obtain cucumber haploids via the use of microspore culture and the results were unsatisfactory in most cases. In the experiments carried out by Suprunova and Shmykova (2008), microspore culture resulted in callus formation from vegetative cells. In China Chen et al. (2008) patented a method for isolated microspore culture of cucumber. The patent describes a procedure from flower bud collection to haploid or DH plant regeneration. However, the data presented is general in nature and does not include the method's efficacy. The following year the same researchers released a publication on cucumber microspore culture (Zhan et al. 2009). Fourteen plants were obtained from two out of four genotypes used. The embryo recovery was 1.5-33.4 embryos per $2 \mathrm{~cm}^{3}$ of a liquid medium containing $2 \times 10^{5}$ microspores. The authors reported that a two-day cold pre-treatment of buds containing microspores at a late uninucleate stage and the addition of $0.5 \mathrm{mg} \mathrm{dm}^{-3} 2,4-\mathrm{D}$ and $0.2 \mathrm{mg} \mathrm{dm}^{-3}$ BA to NLN or B5 medium stimulated haploid embryogenesis. Recently, an attempt to regenerate plants from cucumber microspores has been made by Kiełkowska and Havey (2011). Although the authors experimented with three genotypes of cucumber, applying eight liquid media, a diversified microspore suspension density and low and high temperature pre-treatment, no microspore divisions were observed.

\section{CHROMOSOME DOUBLING IN HAPLOIDS}

In the case of cucurbits, haploid plants are often obtained first, and are subsequently subjected to chromosome duplication. The plants derived from parthenogenetically developed embryos are predominantly haploid and genetically stable, whereas in vitro culture of ovaries and anthers leads to the formation of both haploids and DHs of cucumber (see Table 1).

The procedures for chromosome doubling of cucurbit haploids are mainly based on colchicine treatment (Çağlar and Abak 1997, Nikolova and Niemirowicz-Szczytt 1996, Sari and Abak 1996, Yetisir and Sari 2003), a method that is constantly being revised (Lim and Earle 2008, 2009). Çağlar and Abak (1997) analysed the influence of 
colchicine concentration and treatment duration on chromosome doubling of cucumber haploids in vitro and noted that the highest efficiency of chromosome doubling $(60 \%$ on average) was obtained with the immersion of plantlets in $0.5 \%$ colchicine solution for four hours. Earlier experiments by Nikolova and Niemirowicz-Szczytt (1996) showed that more favourable results could be obtained by multiple applications (3-5 times) of $0.1 \%$ colchicine solution on apical meristems of plants grown in vitro.

Another chromosome doubling method designed for cucumber employs the direct regeneration of plants from haploid leaf explants (NiemirowiczSzczytt et al. 1995), which showed to be more effective than colchicine treatment (SztangretWiśniewska et al. 2006). In their previous research Faris et al. (2000) evaluated the usefulness of direct and indirect regeneration for cucumber haploid doubling. The doubling proved to be more effective (showing higher rate of DH plants among regenerated plants) when indirect regeneration was applied; however, the results are difficult to compare as the haploids submitted to direct and indirect regeneration were derived from different donor plants. Faris et al. (2000) used explants from the first and second haploid leaf in order to directly regenerate $\mathrm{DHs}$ of cucumber. Plants were regenerated from both types of leaves (388 and 210, respectively), however, all plants derived from the first leaf were haploids, whereas the second leaf yielded $70.5 \%$ haploids, $28.2 \%$ diploids and $1.3 \%$ mixoploids. This shows that the developmental age of the tissue being regenerated may be of major significance for the effectiveness of chromosomal doubling.

Whether with the application of colchicine treatment or regeneration from haploid leaves, it is possible to obtain DHs, haploids and plants of different ploidy (i.a. Faris et al. 2000, Claveria et al. 2005, Sztangret-Wiśniewska et al. 2006, Lim and Earle 2008, 2009). Cytological observations have to be performed in order to evaluate the ploidy level of the obtained plants. Typically, the cells of the root apical meristem are used for chromosome count or leaf samples are used in flow cytometry. In cucumber one can distinguish between haploids, diploids and tetraploids on the basis of leaf and flower shape (Sauton 1989, Nikolova and Niemirowicz-Szczytt 1996). However, in the study of Nikolova and Niemirowicz-Szczytt (1996), the ultimate ploidy indicator was the number of chromosomes in the maternal cells of anther.

\section{CONCLUSIONS}

The first haploid plants in the Cucurbitaceae family were obtained in the 1950s. To date, haploid and DH plants were obtained in eight species. Most of these species, especially cucumber, squash, melon and watermelon, are widely grown and are of economic importance. Information on the use of DHLs in breeding programs of particular species is rather sparse. Nevertheless, the main objective of haploid research is to facilitate and accelerate breeding programs, although the number of DHLs produced remains low.

Researchers in various research centres all over the world were successful in inducing haploids in many cucurbit plants through pollination with irradiated pollen. This most popular method of haploid induction is being continuously optimised and applied to an increasing number of cucurbit species. It is also being employed in breeding programmes.

The number of publications on the successful application of in vitro gynogenesis in cucurbit plants is rather small. The results of in vitro ovule and ovary culture indicate a low efficacy of the method and the need for its further optimisation. Recently, interest has been focused on in vitro anther culture and, though to a lower extent, microspore culture as well. A direct comparison of the irradiated pollen technique and anther culture is difficult. In cucumber it is possible to obtain up to 5-10 haploid embryos (which require doubling) per fruit using irradiated pollen. In vitro culture of anthers allows DHs to be obtained directly, with regeneration of up to three embryos per anther. The newest reports suggest that anther culture can provide an equivalent or alternative method of cucumber haploid induction to that of pollination with irradiated pollen. However, our experiments on anther and microspore culture do not confirm the high efficiency of these two methods (unpublished).

Plants obtained from parthenogenetic embryos are predominantly haploids, while the use of ovule or ovary culture and anther or microspore culture allows the induction of both haploids and DHs. Chromosome doubling in haploids is obtained primarily by colchicine application. In cucumber chromosome doubling by plant regeneration from haploid leaf explants has also proved to be effective.

\section{REFERENCES}

Aalders L.E., 1958. Monoploidy in cucumbers. J. Hered. 49: 41-44. 
Abd El-Maskoud M.M., El-Gendy S.E.A., El-Kady M.M., 2009. Genotypes and genotype $\times$ medium composition interaction effects on androgenic haploid production in cucumber (Cucumis sativus L.). J. Agric. Sci. Mansoura Univ. 34(11): 1030510312.

Antos M., BuŁat E., Zawiślak E., 2001. Cucumber (Cucumis sativus L.) haploids induction with use of X-rays (in Polish). Folia Hort. 13(1A): 81-84.

Ari E., Ikten H., Gocmen M., Coskun R., Eren A., 2010. Comparative evaluation of different embryo rescue techniques on parthenogenetic melon (Cucumis melo L.) fruits induced with irradiated pollen. Afr. J. Biotechnol. 9(33): 5347-5356.

Ashok Kumar H.G., Ravishankar B.V., Murthy H.N., 2004. The influence of polyamines on androgenesis of Cucumis sativus L. Eur. J. Hortic. Sci. 5: 201-205.

Ashok Kumar H.G., Murthy H.N., 2004. Effect of sugars and amino acids on regeneration from anther cultures of Cucumis sativus. Plant Cell Tiss. Org. Cult. 78: 201-205.

Ashok Kumar H.G., Murthy H.N., Paek K.Y., 2003. Embryogenesis and plant regeneration from anther cultures of Cucumis sativus L. Sci. Hort. 98: 213-222.

Blakeslee A.F., Belling J., Farnham M.E., Bergner A.D., 1922. A haploid mutant in the Jimson weed, Datura stramonium. Science 55: 646-647.

ÇAĞLAR G., ABAK K., 1996a. The effects of season and irradiation doses on haploid embryo production in cucumber (C. sativus L.). Proc. of the VI ${ }^{\text {th }}$ Eucarpia meeting on Cucurbit genetics and breeding, Malaga, Spain: 25-30.

ÇAĞLAR G., ABAK K., 1996b. Efficiency of haploid production in cucumber. Cucurbit Genetics Coop. Rep. 19: 36-37.

ÇAĞLAR G., ABAK K., 1997. In vitro colchicine application of haploid cucumber plants. Cucurbit Genetics Coop. Rep. 20: 21-23.

Çă̌lar G., Abak K., 1999a. Progress in the production of haploid embryos, plants and doubled haploids in cucumber (Cucumis sativus L.) by gamma irradiated pollen in Turkey. Acta Hort. 492: 317-322.

ÇAĞLAR G., AвAK K., 1999b. In situ haploid embryo induction in cucumber (Cucumis sativus L.) after pollination by irradiated pollen. Turk. J. Agric. For. 23: 63-72.

Chambonnet D., Dumas de Vaulx R., 1985. Obtention of embryos and plants from in vitro culture of unfertilized ovules of Cucurbita pepo. Cucurbit Genetics Coop. Rep. 8: 66.

Chen J., Zhan Y., Qian C., Lou Q., 2008. Cultivation method for isolated microspore of cucumber. Nanjing Agricultural University. Patent no CN 101317548.

Claveria E., Garcia-Mas J., Dolcet-Sanjuan R., 2005. Optimization of cucumber doubled haploid line production using in vitro rescue of in vivo induced parthenogenic embryos. J. Am. Soc. Hort. Sci. 130(4): 555-560.

COST Action 851, 2005. Available online at http://www. scri.ac.uk/assoc/COST851/DHTable2005.xls; cited on 26 Mar 2012.

Cuny F., Grotte M., Dumas de Vaulx R., Rieu A., 1993. Effects of gamma irradiation of pollen on parthenogenetic haploid production in muskmelon (Cucumis melo L.). Environ. Exp. Bot. 33(2): 301-312.

Diao W.-P., Jia Y.-Y., Song H., Zhang X.-Q., Lou Q.F., Chen J.-F., 2009. Efficient embryo induction in cucumber ovary culture and homozygous identification of the regenetants using SSR markers. Sci. Hort. 119(3): 246-251.

DiRKS R., 1996. Method for the production of doublehaploid cucumbers. United States Patent No. $5,492,827$.

Dolcet-Sanjuan R., Claveria E., Garcia-Mas J., 2006. Cucumber (Cucumis sativus L.) dihaploid line production using in vitro rescue of in vivo induced parthenogenic embryos. Acta Hort. 725: 837-844.

Dryanovska O.A., ILIEVA I.N., 1983. In vitro anther and ovule cultures in muskmelon (Cucumis melo L.) Proc. Bulgarian Academy of Sciences 36: 1107-1110.

Dumas DE VAulX R., 1979. Obtention de plantes haploides chez le melon (Cucumis melo L.) apres pollinisation par Cucumis ficifolius A. Rich. C. R. Acad. Sci. III-Vie 289: 875-878.

Dumas de Vaulx R., Chambonnet D., 1986. Obtention of embryos and plants from in vitro culture of unfertilized ovules of Cucurbita pepo. In: Genetic manipulation in plant breeding. W. Horn, C.J. Jensen, W. Odenbach, O. Schieder (eds), Proc. International Symposium EUCARPIA, 8-12 Sept. 1985, Berlin: 295-297.

Dunwell J.M., 2010. Haploids in flowering plants: origins and exploitation. Plant Biotechnol. J. 8: 377-424.

Faris N.M., Nikolova V., Niemirowicz-Szczytt K., 1999. The effect of gamma irradiation dose on cucumber (Cucumis sativus L.) haploid embryo production. Acta Physiol. Plant. 21(4): 391-396.

Faris N.M, Niemirowicz-Szczytt K., 1999. Cucumber (Cucumis sativus L.) embryo development in situ after pollination with irradiated pollen. Acta Biol. Cracov. Bot. 41: 111-118.

Faris N.M., Rakoczy-Trojanowska M., Malepszy S., NiEmirowicz-SzczytT K., 2000. Diploidization of cucumber (Cucumis sativus L.) haploids by in vitro culture of leaf explant. S. Bielecki, J. Tramper, J. Polak (eds), Progr. Biotechnol., Food Biotechnology 17: 49-54.

Ficcadenti N., Sestili S., Annibali S., 1999. In vitro gynogenesis to induce haploid plants in melon (Cucumis melo L.). J. Genet. Breed. 53: 255-257.

Ficcadenti N., Veronese P., Sestili S., Crino P., Lucretti S., Schiavi M. ET AL., 1995. Influence of genotype on 
the induction of haploidy in Cucumis melo L. by using irradiated pollen. J. Genet. Breed. 49: 359-364.

Forster B.P., Heberle-Bors E., Kasha K.J., Touraev A., 2007. The resurgence of haploids in higher plants. Trends Plant Sci. 12(8): 368-375.

GÉmes JuhÁsz A., JAKŠE M., 2005. Haploid induction in Cucurbitaceae species. In: Biotechnology in Agriculture and Forestry. Haploids in crop improvement II. C.E. Palmer, W.A. Keller, K.J. Kasha (eds), Springer-Verlag, Berlin.

Gémes Juhász A., Balogh P., Ferenczy A., Kristóf Z., 2002. Effect of optimal stage of female gametophyte and heat treatment on in vitro gynogenesis induction in cucumber (Cucumis sativus L.). Plant Cell Rep. 21: 105-111.

Gémes JuhÁsz A., Venczel G., Balogh P., 1997. Haploid plant induction in zucchini (Cucurbita pepo L. convar. giromontiina Duch) and in cucumber (Cucumis sativus L.) lines through in vitro gynogenesis. Acta Hort. 447: 623-625.

Godbole M., Murthy H.N., 2012. Parthenogenetic haploid plants using gamma irradiated pollen in snapmelon (Cucumis melo var. momordica). Plant Cell Tiss. Org. Cult. 109: 167-170.

Gonzalo M.J., Olivier M., Garcia-Mas J., Monfort A., Dolcet-Sanjuan R., Katzir N. et Al., 2005: Simple-sequence repeat markers used in merging linkage maps of melon (Cucumis melo L.). TAG 110: 802-811.

Gürsöz N., Abak K., Pitrat M., Rode J.C., Dumas de VAULX R., 1991. Obtention of haploid plants induced by irradiated pollen in watermelon (Citrillus lanatus L.). Cucurbit Genetics Coop. Rep. 4: 109-110.

Hayase H., 1954. Cucurbita crosses. Occurrence of a haploid twin pair from a $\mathrm{F} 1$ progeny of $C$. maxima $\times$ C. moschata. Jpn. J. Breed. 4: 55.

KieŁkowska A., Havey J.H., 2011. Studies on in vitro culture of cucumber microspores. Proc. Plant \& Animal Genomes XIX Conference, 15-19 January, San Diego, USA. Paper No. P871.

Kumar H., 1984. Differentiation in anther culture of two cucurbits. Genetic manipulation in crops: proceedings of the International Symposium on Genetic Manipulation in Crops, the $3^{\text {rd }}$ International Symposium on Haploidy, the $1^{\text {st }}$ International Symposium on Somatic Cell Genetics in Crops, Beijing: 45-47.

Kurtar E.S., Balkaya A., Ozbakir M., Ofluoglu T., 2009. Induction of haploid embryo and plant regeneration via irradiated pollen technique in pumpkin (Cucurbita moschata Duchesne ex. Poir). Afr. J. Biotechnol. 8(21): 5944-5951.

Kurtar E.S., Balkaya A., 2010. Production of in vitro haploid plants from in situ induced haploid embryos in winter squash (Cucurbita maxima Duchesne ex Lam.) via irradiated pollen. Plant Cell Tiss. Org. Cult. 102(3): 267-277.
Kurtar E.S., SARi N., AbaK K., 2002. Obtention of haploid embryos and plants through irradiated pollen technique in squash (Cucurbita pepo L.). Euphytica 127: 335-344.

Kuzuya M., Hosoya K., Yashiro K., Tomita K., Ezura H., 2003. Powdery mildew (Sphaerotheca fuliginea) resistance in melon is selectable at the haploid level. J. Exp. Bot. 54(384): 1069-1074.

KWACK S.N., FuJIEdA K., 1988. Somatic embryogenesis in cultured unfertilized ovules of Cucurbita moschata. J. Jpn. Soc. Hort. Sci. 57: 34-42.

Lazarte J.E., Sasser C.C., 1982. Asexual embryogenesis and plantlet development in anther culture of Cucumis sativus L. HortScience 17: 88.

Le Deunff E., Sauton A., 1994. Effect of parthenocarpy on ovule development in cucumber (Cucumis sativus L.) after pollination with normal and irradiated pollen. Sex. Plant Reprod. 7(4): 221-228.

Li J., Zhang L., Li H.-X., Gong G.-Y., Zhang H.-Y., Guo S.-G. ET AL., 2008. Development of anther culture technique in watermelon (Cirtullus lanatus) China Cucurbits and Vegetables 2008-04-006. Available online at http://en.cnki.com.cn/Article_en/ CJFDTOTAL-ZGXG200804006.htm, cited on 10 Dec 2012.

Lim W., EARLE E.D., 2008. Effect of in vitro and in vivo colchicine treatments on pollen production and fruit set of melon plants obtained by pollination with irradiated pollen. Plant Cell Tiss. Org. Cult. 95: 115124.

Lim W., EARLE E.D., 2009. Enhanced recovery of doubled haploid lines from parthenogenetic plants of melon (Cucumis melo L.). Plant Cell Tiss. Org. Cult. 98: 351-356.

Lofti M., Alan A.R., Henning M.J., Jahn M.M., Earle E.D., 2003. Production of haploid and double haploid plants of melon (Cucumis melo L.) for use in breeding for multiple virus resistance. Plant Cell Rep. 21: 1121-1128.

Lofti M., Kashi A., Onsinejad R., 1999. Induction of parthenogenetic embryos by irradiated pollen in cucumber. Acta Hort. 492: 323-326.

Lofti M., SAlehi S., 2008. Detection of cucumber parthenogenic haploid embryos by floating the immature seeds in liquid medium. In: Cucurbitaceae 2008, Pitrat M. (ed.). Proc. IX ${ }^{\text {th }}$ EUCARPIA meeting on genetics and breeding of Cucurbitaceae, 21-24 May, Avignon, France: 375-380.

Metwally E., Moustafa S.A., El-Sawy B.I., Harun S.A, Shalaby T.A., 1998a. Production of haploid plants from in vitro culture of unpollinated ovules of Cucurbita pepo. Plant Cell Tiss. Org. Cult. 52(3): 117-121.

Metwally E., Moustafa S.A., El-Sawy B.I., Shalaby T.A., 1998b. Haploid plantlets derived by anther culture of Cucurbita pepo. Plant Cell Tiss. Org. Cult. 52(3): 171-176. 
Mohamed M.F., Refaei E.F.S., 2004. Enhanced haploids regeneration in anther culture of summer squash (Cucurbita pepo L.). Cucurbit Genetics Coop. Rep. 27: 57-60.

Niemirowicz-Szczytt K., Delis M., Fedorowicz O., Galecka T., Korzeniewska A., Sztangret J., 2001. Cucumber (Cucumis sativus L.) haploid induction, doubling and preliminary evaluation of DH lines. Folia Hort. 13(1A): 137-142.

Niemirowicz-Szczytt K., Dumas de Vaulx R., 1989. Preliminary data on haploid cucumber (Cucumis sativus L.) induction. Cucurbit Genetics Coop. 12: 24-25.

Niemirowicz-Szczytt K., Faris N.M., Nikolova, V., Rakoczy-Trojanowska M., Malepszy S., 1995. Optimization of cucumber (Cucumis sativus L.) haploid production and doubling. In: Cucurbitaceae '94, G. Lester (ed.): 169-171.

Nikolova V., Niemirowicz-SzczytT K., 1996. Diploidization of cucumber (Cucumis sativus L.) haploids by colchicine treatment. Acta Soc. Bot. Pol. 65: 311-317.

Przyborowski J.A., 1996. Haploidy in cucumber (Cucumis sativus L.). In: In vitro haploid production in higher plants. Important selected plants. S. Mohan Jain, S.K. Sopory, R.E. Veilleux (eds), Kluwer Academic Publishers, Dordrecht, The Netherlands.

Przyborowski J.A., Niemirowicz-Szczytt K., 1992. Haploids induction in Cucumis sativus L. and their preliminary description. Proc. Eucarpia Meeting on Cucurbitaceae, Warsaw-Skierniewice: 87-90.

Przyborowski J. A., Niemirowicz-Szczytt K., 1994. Main factors affecting cucumber (Cucumis sativus L.) haploid embryo development and haploid plant characteristics. Plant Breeding 112: 70-75.

SARi N., ABAK K., 1996. Effect of different colchicines doses and application period in dihaploidization of haploid watermelon plants. Turk. J Agric. For. 20: 555-559.

Sari N., Abak K., Pitrat M., Rode J.C., Dumas de Vaulx R., 1994. Induction of parthenogenetic haploid embryos after pollination by irradiated pollen in watermelon. HortScience 29: 1189-1190.

Sari N., Solmaz I., Kasapoglu S., Gursoy I., Szamosi C., UnLu H. ET AL., 2010. Effect of different pollination dates with irradiated pollens on fruit set, haploid embryo induction and plant obtention in Turkish (Kirkagac, Yuva and Hasanbey) melons. Acta Hort. 871: 639-648.

SAUTON A., 1988. Effect of season and genotype on gynogenetic haploid production in muskemlon, Cucumis melo L. Sci. Hort. 35(1-2): 71-75.

SAuton A., 1989. Haploid gynogenesis in Cucumis sativus induced by irradiated pollen. Cucurbit Genetics Coop. 12: 22-23.

Sauton A., Dumas de Vaulx R., 1987. Production of haploid plants in melon (Cucumis melo L.) as a result of gynogenesis induced by irradiated pollen. Agronomie 7: 141-147.

Sauton, A., Dumas de Vaulx R., 1988. Doubled haploid production in melon (Cucumis melo L.). Proc. Eucarpia Meeting on Cucurbitaceae, AvignonMonfavet, France: 119-128.

Savin F., Decombe Le-Couriour M., Hallard J., 1988. The X-Ray detection of haploid embryos arisen in muskmelon (Cucumis melo L.) seeds and resulting from a parthenogenetic development induced by irradiated pollen. Cucurbit Genetics Coop. 11: 36-42.

Sestili S., Ficcadenti N., 1996. Irradiated pollen for haploid production. In: In vitro haploid production in higher plants: Oil, Ornamental and Miscellaneous Plants. J. Mohan Jain, S.K. Sopory and R.E. Veilleux (eds): Kluwer Academic Publishers, Dordrecht, Netherlands: 263-274.

Shail J.W., Robinson R.W., 1987. Anther and ovule culture of Cucurbita. Cucurbit Genetics Coop. 10: 92.

Shalaby T.A., 2007. Factors affecting haploid induction through in vitro gynogenesis in summer squash (Cucurbita pepo L.). Sci. Hort. 115(1): 1-6.

Song H., Lou Q.-F., Luo X.-D., Wolukau J.N., Diao W.P., QiAn C.-T. ET AL., 2007. Regeneration of doubled haploid plant by androgenesis of cucumber (Cucumis sativus L.). Plant Cell Tiss. Org. Cult. 90: 245-254.

Suprunova T., Shmykova N., 2008. In vitro induction of haploid plants in unpollinated ovules, anther and microspore culture of Cucumis sativus. In: Cucurbitaceae 2008. M. Pitrat (ed.). Proc. IX ${ }^{\text {th }}$ EUCARPIA meeting on genetics and breeding of Cucurbitaceae. 21-24 May, Avignon, France.

Swaminathan M.S., Singh M.P., 1958. X-ray induced somatic haploidy in watermelon. Curr. Sci. India 27: 63-64.

Sztangret-Wiśniewska J., GaŁecka T., Korzeniewska A., Marzec L., Kolakowska G., Piskurewicz U. ET AL., 2006. Characteristics of double-haploid cucumber (Cucumis sativus L.) lines resistant to downy mildew (Pseudoperonospora cubensis [Berk. et Curt.] Rostovzev). Proc. Cucurbitaceae 2006. G.J. Holmes (ed.). Raleigh, North Carolina, USA: 515-526.

TANG Y., Li X., Li J., Ma C., Lai J., Li H., 2012. Effect of different pretreatment on callus formation from anther in balsam pear (Momordica charantia L.). J Med. Plants Res. 6(17): 3393-3395.

TruOnG-Andre I., 1988. In vitro haploid plants derived from pollination by irradiated pollen of cucumber. Proc. Eucarpia Meeting on Cucurbit Genetics and Breeding, 31 May-2 June, Avignon-Montfavet, France: 143-144.

XIE B., WANG X.-F., FAN Z.-C., 2006. Improved conditions of in vitro culture of unpollinated ovules and production of embryonary sac plants in summer squash (Cucurbita pepo L.) Sci. Agric. Sinica 39(1): $132-138$ 
XIE M., QIN L.-Y., PAN J.-S., He H.-L., Wu A.-Z., CAI R., 2005. Flower morphogenesis and microspore development versus anther culture of cucumber. Act. Bot. Bor.-Occ. Sinica. Available online at http://en.cnki.com.cn/Article_en/CJFDTOTALDNYX200506005.htm; cited on 10 Dec 2012.

Xue G.R., Yu W.Y., Fei K.W., 1983. Watermelon plants derived by in vitro anther culture. Plant Physiol. Commun. 4: 40-42.

Yanmaz R., Ellialtioglu S., Taner K.Y., 1999. The effect of gamma irradiation on pollen viability and haploid plant formation in snake cucumber (Cucumis melo L. var. flexosus Naud.). Acta Hort. 492: 307-310.

Yetisir H., SAri N., 2003. A new method for haploid muskmelon (Cucumis melo L.) dihaploidization. Sci. Hort. 98: 277-283.

Zagorcheva L., Alexandrova M., Kichukova C., 1987. Pollen mother cell meiosis in the haploid of Cucumis ficifolius A. Rich. Cucurbit Genetics Coop. Rep. 10: 37-38.

Zhan Y., Chen J., Abbas Malik A., 2009. Embryoid induction and plant regeneration of cucumber (Cucumis sativus L.) through microspore culture. Acta Hort. Sinica 36(2): 221-226.

\section{PRZEGLĄD BADAŃ NAD HAPLOIDAMI OGÓRKA I INNYCH ROŚLIN DYNIOWATYCH}

Streszczenie: Niniejsze opracowanie obejmuje historyczny i metodyczny opis metod otrzymywania haploidów ogórka (Cucumis sativus L.), melona (Cucumis melo L.), arbuza (Citrullus lanatus (Thunb.) Matsum. \& Nakai), dyni olbrzymiej (Cucurbita maxima Duch. ex Lam.), dyni zwyczajnej (Cucurbita pepo L.) i innych roślin dyniowatych oraz czynniki wpływające na wydajność poszczególnych metod. W szczególności opracowanie dotyczy badań prowadzonych w ciągu ostatnich dwudziestu lat.
Głównym celem badań nad haploidami jest otrzymanie linii podwojonych haploidów, które są homozygotyczne, co może przyspieszyć proces hodowli, chociaż liczba otrzymywanych linii jest zwykle mała. Zastosowanie podwojonych haploidów w trakcie hodowli może również ułatwić wyselekcjonowanie określonych roślin, na przykład odpornych na choroby.

Najczęściej stosowaną i najlepiej poznaną metodą otrzymywania haploidów roślin dyniowatych jest zapylenie napromieniowanym pyłkiem, które indukuje partenogenetyczny rozwój haploidalnych zarodków na roślinie (in planta). Zarodki izoluje się i poddaje kulturze in vitro w celu regeneracji roślin. Prace nad zastosowaniem tej metody poświęcone były przede wszystkim ustaleniu odpowiedniej dawki promieniowania oraz wpływu genotypu i pory roku na liczbę otrzymywanych zarodków i roślin haploidalnych.

Mniej popularną metodą otrzymywania haploidów jest kultura zalążków i zalążni, wykorzystująca zjawisko gynogenezy in vitro. W przypadku tej metody badania skupiły się na ustaleniu składu pożywki i sposobu traktowania wstępnego pąków kwiatowych (wysoka lub niska temperatura).

W ostatnich latach wzrosło zainteresowanie kulturą in vitro pylników, oraz w mniejszym zakresie kulturą mikrospor (androgeneza in vitro). Podobnie jak w przypadku gynogenezy in vitro, optymalizacji podlegały przede wszystkim skład pożywki oraz traktowanie wstępne pąków kwiatowych. Wyniki najnowszych badań pozwalają przypuszczać, że kultura pylników może być równorzędną metodą otrzymywania haploidów ogórka w stosunku do zapylenia napromieniowanym pyłkiem.

Received February 5, 2013; accepted May 24, 2013 